\title{
Production Systems and Income Generation from the Smallholder Beef Cattle Farming In Yogyakarta Province, Indonesia
}

\author{
Rini Widiati ${ }^{1)^{*}}$ and Tri Satya Mastuti Widi ${ }^{2)}$ \\ 1)Department of Socio Economic, Faculty of Animal Science, Universitas Gadjah Mada, Yogyakarta, Indonesia \\ 2)Department of Animal Production, Faculty of Animal Science, Universitas Gadjah Mada, Yogyakarta, Indonesia \\ *Corresponding author email: rini_w@ugm.ac.id
}

\begin{abstract}
This study was aimed to determine the production systems of beef cattle which can generate the income of smallholder farmers. The study was conducted in Bantul and Sleman Regencies, Yogyakarta Province, Indonesia. In total of 210 beef cattle farmers were involved in semi structural interview. Data was collected in the dry season (July to September) of 2015. Descriptive analysis was carried out for the demographic, social, economic characteristic of respondents and beef cattle farm practices. Enterprise budgeting of beef cattle farms was made to analyze farm profit, return to management and family labour that could be used in further planning for better business management. Beef cattle farming founded as an alternative that can be developed in rural communities. In order to generate the incomes in both systems, breeding and fattening, production system in term of feeding practices has to be improved so that the cost can be reduced. Scientific processing of manure has to be done for value addition in the farming system. Calving interval has to be improved in breeding system, that the best condition is 12 months and the existing condition on the respondents was 16 months. For fattening, optimizing the duration for fattening period less than 3.6 months is the best improvement. Government policy is needed to improve beef farm economic condition especially in breeding farm.
\end{abstract}

Key words: Beef cattle farming, enterprise budgeting, farm profit, family labour, production system and return to management.

Abstrak. Penelitian ini bertujuan untuk menentukan sistem produksi sapi potong yang dapat menghasilkan pendapatan petani kecil. Penelitian dilakukan di Bantul dan Kabupaten Sleman, Provinsi Yogyakarta, Indonesia. Total 210 responden sapi potong terlibat dalam wawancara dengan metode semi structural. Data dikumpulkan pada musim kemarau (Juli-September) 2015. Analisis deskriptif dilakukan untuk mengetahui kondisi demografi, karakteristik sosial ekonomi responden dan pengelolaan peternakan sapi. Enterprise budgeting digunakan untuk menganalisis keuntungan, penerimaan dari manajemen dan penggunaan tenaga kerja keluarga pada usaha sapi potong, yang dapat digunakan untuk perencanaan usaha dalam manajemen bisnis yang lebih baik. Hasil penelitian menunjukkan usahatani sapi potong merupakan alternatif yang dapat dikembangkan untuk masyarakat pedesaan. Dalam rangka untuk menghasilkan pendapatan yang lebih baik pada usaha pembibitan dan penggemukan, sistem pemberian pakan harus diperbaiki sehingga biaya bisa ditekan namun memenuhi syarat kebutuhan, teknologi pengolahan pupuk perlu dilakukan untuk dapat memberikan nilai tambah. Calving interval dalam sistem usaha pembibitan harus diperbaiki, dimana kondisi terbaik adalah 12 bulan dan kondisi yang ada pada responden adalah 16 bulan. Pada usaha penggemukan, perlu mengoptimalkan lamanya periode penggemukan lebih cepat dari kondisi saat ini 3,6 bulan. Kebijakan pemerintah diperlukan untuk memperbaiki kondisi ekonomi peternakan sapi terutama pada usaha pembibitan.

Kata kunci:, peternakan sapi potong, enterprise budgeting, tenaga kerja keluarga, sistem produksi dan keuntungan manajemen

\section{Introduction}

Since 2005, Indonesian government has been launching a beef meat self-sufficiency program, with one of its criteria was that the maximum import of beef meat must be less than $10 \%$. However, this program seems to be unsuccessful, since the importation of beef meat has reached to $33.2 \%$ of the total national beef consumption (CBS, 2013; Widiati, 2014). About $95 \%$ of beef cattle production is in 
smallholder farming systems which characterized by less than 5 heads of cattle per household (Widi, 2015) because of lack of capital. In rural areas, farmers keep livestock as a living bank which can be sold by farm families at any time to meet the family needs in the time of financial constraints (Widiati, 2012; Verschelde et al., 2013; Huyen et al., 2012) also reported that, resources of smallholder farmers in developing countries are limited to meet as per varied agricultural conditions, such as land and soil fertility, types of crops and livestock farming. Ndoro (2014) has also pointed out that in rural South Africa, the sustainability of cattlebased livelihoods is threatened by competition for natural resources such as land and water. However, it is believed that animals are kept by smallholder farmers to eliminate poverty, especially in the poor and developing countries (Lloyd et al., 2014). Maart-Noelck and Musshoff (2013) stated that the behaviour of farmers in decision making to invest in order to expand its business was to learn from previous investments and judgement of the value obtained from the enterprise time to time. If the investment is supposed to provide added value or benefit, only then the farmers will decide to invest. Therefore, the smallholder livestock farmers need to understand their production systems to plan and decide for profitable business activity. Enterprise budgeting is a tool that can be used for decision making of the farmers in order to increase profits. Only a proper and correct analysis will lead to making the right decision (Kay et al., 2008). Paudel et al. (2013) used enterprise budgeting as a tool to determine a decision of input strategy on peanut crop based on its economic criteria. Enterprise budgeting is an accounting technique which can be used to handle problems related to scale of economies, replacement of durable inputs, inflation and technological change. It can help farmers to plan for profits from the enterprise (Bradford and Debertin, 1985).
The combination of budgeting and economic principles provides some powerful, practical, and useful techniques for the manager/farmer to use when analyzing alternatives that are suitable for the farmer. In these perspectives, present study was carried out with the objective to determine the production systems of beef cattle which can generate the income of smallholder farmers in Yogyakarta Province, Indonesia.

\section{Materials and Methods}

\section{Study areas}

Yogyakarta Province is considered as a densely populated area and one of beef cattle sources in Java. In 2012, the human population was 3.71 million, beef cattle population was about 414,381 heads, and agricultural land was about 132,987 ha. In 2007-2012 beef cattle population increased by $8.81 \%$ exceeding the national increase which was only $6.78 \%$ (CBS, 2013).Two districts, Sleman and Bantul were used as study areas. Both areas are both lowland and fertile, consequently these areas had abundance of feed resources for cattle. Quantitative and qualitative data were descriptively analysed.

\section{Data collection}

A total 210 smallholder farmers in the 2 districts (90 farmers in Sleman and 120 farmers in Bantul) were selected as respondents in this study, which was proportionally determined based on population density of these areas. The samples of the farmers were identified through administrative services using snowball sampling method to make accurate estimates about characteristics of hidden populations such as smallholder's activities (Salganik and Heckathorn, 2004; Heckarthorn, 2011). Data collection was done during the dry season, (July to September 2015). The farmers were individually interviewed using semi structured questionnaire. The questionnaire contained the following topics: identity of the respondent, 
production systems of beef cattle farming and performance of the cattle. The administrative services in the study areas accompanied and facilitated us during data collection. The amounts of feeds were estimated on the basis of farmers' estimates and direct observation on kinds and amounts of feeds offered to each animal. Average of body weights (BW, in $\mathrm{kg}$ ) of the cattle were estimated by measuring girth of chest $(\mathrm{GC}$, in $\mathrm{cm})$ and transformed the average of GC using measurement tape (developed by FHK Ogawa Seki Co. Ltd, Tokyo, Japan).

\section{Data analysis}

Both quantitative and qualitative variables were derived from questionnaires by tabulating and editing the data that was used as a basis for further analysis. The data can be grouped as follows; (1) Identification of beef cattle production systems: location, environment, and information of techniques that were done and affected the inputs used and outputs produced; (2) Farm structures: availability of family labour, education and experience of the farmers, available cropland and the livelihoods of family farmers; (3) Livestock performances: feeding, housing, breeding system, service per conception $(\mathrm{S} / \mathrm{C})$, calving interval, and fattening system; and (4) Economics variables : price of inputs and outputs

Quantitative and qualitative data were descriptively analysed. The enterprise budgeting for beef cattle farm was made to analyse profitability, return to management and family labour that could be used for further planning for farmers to better business conditions (Paudel et al., 2013; Kay et al., 2008; Bradford \& Debertin, 1985).

\section{Results and Discussion}

\section{Characteristics of the farmers}

Most of the farmers had formal education. The average of respondents went to junior high school (9 years of formal education) and continued to senior high school. High level of education makes them easier to adopt the technology than lower level of education, such as primary school (Gowda and Dixit, 2015). The average of experience of cattle keeping was more than 14 years (Table 1). The ownership of cattle was about 3 heads consisting of a cow, steer, heifer and calf. The average cropping land was about $1,000 \mathrm{~m} 2$. The condition indicated that farmers are categorized as small businesses operation with limited supporting resources. However, farmers were always looking for opportunities to increase income, such as raising beef cattle. They have implemented forage fermentation technology, cultivated grasses, feed concentrates with existing local raw materials and may be purchased from feed factory in accordance with existing capital, as well as the artificial insemination for cattle with special breeds. Instead of buying forages, farmers utilizing crops by-products, cultivating grasses in the edge of the rice field and browsing crop byproducts. In this study, the cost of procurement of forage was converted as the opportunity cost of family labour. Table 1 shows the characteristics of the farmers.

\section{Production systems of beef cattle farming}

As in other areas in Indonesia, in these study areas, cattle are kept in mixed farming systems and serve many objectives such as saving, producing manure, draught power and social and status (Widiati, 2006; Widiati, 2014). Livestock as a living bank, be indicated that farmers would sell their animals at any time to meet their special needs such as school fees, repair homes, and social needs of the community, so the livestock sold has not yet reached the maximum age for profit (Widiati, 2014). Breeders have a narrow agricultural land was about $1000 \mathrm{~m}^{2}$ of flat land so that on the season of tilling, then the cattle used to pull plows. Using of tractors on small land will not be efficient or high cost. Beef cattle produce faeces as fertilizer for organic crops was much needed by Indonesian farmers. 
Table 1. Characteristics of the farmers in the two study areas $(n=210)$

\begin{tabular}{|c|c|c|c|}
\hline No. & Characteristics & Average & Deviation standard \\
\hline \multirow[t]{5}{*}{1} & Number of family members based on age & 3.84 & 1.79 \\
\hline & - $>50$ years $(\%)$ & & 33 \\
\hline & - $15-49$ years $(\%)$ & & 51 \\
\hline & - $5-14$ years $(\%)$ & & 12 \\
\hline & - $1-5$ years $(\%)$ & & 4 \\
\hline 2 & Formal education household head (years) & 10.01 & 3.02 \\
\hline 3 & Experience on keeping cattle (years) & 14.2 & 9.4 \\
\hline 4 & Agricultural land size $\left(\mathrm{m}^{2}\right)$ & $1,022.5$ & $1,813.0$ \\
\hline 5 & Beef cattle ownership (head) & 2.6 & 1.6 \\
\hline 6 & Off farm income (IDR/year) & $1,952,000$ & $2,072,000$ \\
\hline \multirow[t]{7}{*}{7} & Main occupation (\%) & & \\
\hline & - Crop farming (\%) & & 80.5 \\
\hline & - Farm worker (\%) & & 32.9 \\
\hline & - Off farm worker (\%) & & 22.4 \\
\hline & - Trader (\%) & & 10.0 \\
\hline & - Private business (\%) & & 9.1 \\
\hline & - Civil servant (\%) & & 12.4 \\
\hline
\end{tabular}

The production systems were highly depend on the availability of resources, capital and farmers' family labours. They utilised crop by product, due to limitation of land ownership. Despite their capability as a smallholder in a farm scale, farmers adopted technology such as reproduction, good breeding and feeding practices, they tend to concern to particular system, such as breeding and fattening. This is according to research from Huyen et al. (2011). The production systems and the availability of supporting resources will produce technical and economic parameters, as presented in Table 2 and Table 3.

\section{Feeding Practices}

All farms, both breeding and fattening systems, used stall-feeding. Table 2 and 3 provide information regarding the forages and concentrates which were offered to the cattle. The average of body weight estimation of the cows and cattle in breeding and fattening system were 349 and $419 \mathrm{~kg}$, respectively. The amount of forages and concentrates which were offered to cattle in breeding and fattening systems seems to be less $(8.8 \%$ and $8.5 \%$ of body weight, respectively). It is in accordance with a research result in Vietnam that performance of fattening cattle was poor which is due to low supply of concentrate and crude protein supplement in the diet. Furthermore, Syamsu et al. (2014) explained that smallholder farmers have major constraint to provide balanced nutrients in the basal diet.

\section{Management of Reproduction}

Farmers in the study areas were familiar with applied artificial insemination, immediately after oestrus was expressed. No natural mating was used. The farmers usually called the inseminators in their areas. However, the number of inseminators was limited (one person / subdistrict with 200-500 heads of cow). The service per conception (S/C) was ranging between 1-2 times and calving interval reached 16 months. The farmers reported that they usually wean their calves in the $3^{\text {rd }}$ $-4^{\text {th }}$ of month and sell the calves to get cash money immediately, as cattle serve as saving for them. 
Table 2.Technical and economic parameters of the beef cattle breeding

\begin{tabular}{lcc}
\hline \multicolumn{1}{c}{ Description } & Averages & Deviation Standard \\
\hline Beef cattle breeding ( $\mathrm{n}=126$ : Sleman $(\mathrm{n}=66)$ and Bantul $(\mathrm{n}=60)$ ) & & \\
Technical Parameters & & \\
Forage (kg/head/day) & 28.7 & 2.4 \\
Concentrate (kg/head/day) & 2.1 & 2.4 \\
Service per Conception, S/C (time) & 1.9 & 1.4 \\
Calving interval, Cl (month) & 16.0 & 1.9 \\
Age of calf weaning (month) & 3.5 & 1.4 \\
Girth of chest (cm) & 165.52 & 14.83 \\
Body weight estimation (kg) & 349 & \\
Economic Parameters & & \\
Price of concentrate (IDR/kg) & 2,298 & 265 \\
Price of forages (IDR/kg) & 304 & 91 \\
Price of cow (million IDR) & $1 ., 94$ & 1.01 \\
Price of calf (million IDR) & 7.35 & 1.20 \\
\hline
\end{tabular}

Table 3.Technical and economic parameters of the beef cattle fattening

\begin{tabular}{|c|c|c|}
\hline Description & Averages & Deviation Standard \\
\hline \multicolumn{3}{|c|}{ Beef cattle fattening $(n=84:($ Sleman $(n=54)$ and Bantul $(n=30))$} \\
\hline \multicolumn{3}{|l|}{ Technical Parameters } \\
\hline Forage $(\mathrm{kg} / \mathrm{head} /$ day) & 30.6 & 6.7 \\
\hline Concentrate $(\mathrm{kg} / \mathrm{head} / \mathrm{day})$ & 5.2 & 1.7 \\
\hline Fattening period (month) & 3.6 & 1.5 \\
\hline Girth of chest $(\mathrm{cm})$ & 176.25 & 20.19 \\
\hline Body weight estimation $(\mathrm{kg})$ & 419 & \\
\hline \multicolumn{3}{|l|}{ Economic Parameters } \\
\hline Price of concentrate (IDR/kg) & 2,780 & 214.16 \\
\hline Price of forage (IDR/kg) & 319,5 & 59.9 \\
\hline Price of feeder cattle (million IDR/head) & 11.95 & 3.56 \\
\hline Price of fattened cattle (million IDR/head) & 17.62 & 3.38 \\
\hline Increase of selling price (million IDR/head) & 5.67 & 2.68 \\
\hline Price of beef (IDR/kg live weight) & \multicolumn{2}{|c|}{40,000} \\
\hline Price of faeces (IDR/kg) & \multicolumn{2}{|c|}{125} \\
\hline
\end{tabular}

It is in accordance with Widi et al. (2015) stated that most of farmers selling the progenies immediately after weaning to obtain immediate profit and to avoid further risk. The farmers usually do not retain 'good calves' in their farm, to obtain higher prices with very few inputs and avoiding risks of low growth rates. The weaned calves were usually kept by more commercially oriented farmers who had better access to feed resources. To shorten the calving interval, good cattle keeping management, especially reproduction and breeding must be done. However, external supports such as capable inseminators and good infrastructure from government have to be available.

\section{Enterprise Budget for Beef Cattle Farming}

Technical and economic parameters were used as the basis for building the enterprise budgeting. Generally, beef cattle farmer were not specifically commercial business orientation 
in a particular purpose. However the output of livestock farming can be divided into breeding that produce calves or growing cattle and feeder cattle for fattening. Furthermore, enterprise budgeting for breeding and fattening cattle is presented in Table 4 and 5 . There were 3 types of breeds either for breeding or fattening, namely Ongole, Simmental and Limousine crosses. In this study we took an average of the three breeds, since the breeds have not been identified individually.

Table 4 showed that the costs of health care was allocated very small in value because government provided it in the form of subsidies for all farmers, especially worm medicine. Table 4shows the beef cattle breeding farming generates negative profit, this is in line with previous studies in other locations (Widiati, 2012). Nevertheless, farmers did not realize it because they only consider the return of income derived from management and labour which are positive. Based on enterprise budgeting for breeding, some aspects that can be improved to increase profits are: shortening the calving interval and processing solid and liquid fertilizers in order to obtain value added.

It should be supported by government regulation, such as increasing calf selling price and low interest rate of credit $(<6 \%)$, while for fattening the break-even point (BEP) price was $\mathrm{Rp} 2,282,000$ /period. It was resulted from beef cattle fattening in the period of 3.6 months. It must produce cattle with the selling price above Rp 2,282,000.

Table 4. Enterprise budget for beef cattle breeding (per cow/year)

\begin{tabular}{|c|c|}
\hline Item & (IDR/th) \\
\hline \multicolumn{2}{|l|}{ Revenue } \\
\hline Increase of selling price $*$ ) & $5,690,000$ \\
\hline Fertilized since 110 days (3.6 months) : 10 kg/day @ IDR 125,-/kg & 137,950 \\
\hline Total revenue (IDR/steer/3.56 months (A) & $5,827,950$ \\
\hline \multicolumn{2}{|l|}{ Cost } \\
\hline \multicolumn{2}{|l|}{ Fixed cost } \\
\hline Interest rate of capital ( $2 \% / 4$ months from price of feeder cattle IDR $12,000,000$ ) & 240,000 \\
\hline Depreciation of housing/4months & 334,000 \\
\hline \multicolumn{2}{|l|}{ Variable cost } \\
\hline Forage feed (30,56 Kg @ IDR 320/kg) (D) & $1,075,712$ \\
\hline Concentrate ( 5.24 kg/day @ IDR 2,780) & $1,602,392$ \\
\hline Equipment (brooms, buckets, shovels) & 44,249 \\
\hline Medical & 12,000 \\
\hline Labour of keeping outside of grassing (E) & 475672 \\
\hline \multicolumn{2}{|l|}{ ( 0.5 hour/day/head) } \\
\hline Land charge (IDR/4 month) & 50,000 \\
\hline Total cost/feeder/3.6 months (B) & $2,282,641$ \\
\hline Estimated profit $(C)=A-B$ & $3,545,309$ \\
\hline \multicolumn{2}{|l|}{ Estimated return to management and family labour $=D+E+C$} \\
\hline (IDR/cattle/4 months) & $5,096,695$ \\
\hline
\end{tabular}


In the rural areas where job opportunities are limited, therefore, even though the marginal value of labour was low but positive, so that farming activities were remain as a choice (Widiati, 2012). Despite of lack of government policy, resulting on farmers' value exchange was lower than input costs (Stur et al., 2013). Therefore, to increase farmers' wealth and stimulate the production of beef cattle in order to meet self-sufficiency of beef, the Indonesian government should provide support for beef product especially in breeding farm. Penson et al. (2002), states that the government intervention was needed in the agriculture to improve farm economic condition among other things was price and income support payments. In this case needed intervention in the form policy of input price subsidized or determination of the beef floor prices so that their farm activity is profitable. In addition, it also gives loans with subsidized interest rates ( $<6 \% /$ year) so that farmers can pay input of technology to increase farm productivity.

\section{Conclusions}

The beef cattle farming was an alternative source of income for the rural communities. In order to generate income in both systems, breeding and fattening, production system in term of feeding practices should be improved and processing of manure has to be done to add value. Calving interval in breeding system has to be improved. For fattening, optimizing the duration of fattening period less than 3.6 months and increase in selling value that was greater than the price of the BEP are the best improvement. It requires government policies, such as determination of beef floor price, input price subsidized and low interest rate of credit especially in breeding farm.

\section{Acknowledgement}

The authors would like to thank to Directorate General of Higher Education,
Ministry of Research, Technology and Higher Education, Republic Indonesia for supporting this study through a research grant. The authors acknowledge the support of Universitas Gadjah Mada, staff members of Livestock Bureaus in Yogyakarta Province, and farmers in the study areas. Last but not least, the authors would like to thank the fresh graduates as local facilitators for their support and assistance in collecting the data.

\section{References}

Bradford GL and DL Debertin. 1985. Establishing linkages between economic theory and enterprise budgeting for teaching and extension programs. Southern Journal of Agricultural Economics. 02: 67-76.

CBS (Central Berau of Statistic). 2013. Census of Agriculture in Indonesia. Press release of statistics No. 62/09/ XVI, Sept. 2013, 1-5. Ministry of Agriculture, Jakarta

Gowda MJC and S Dixit. 2015. Influence of farmers educational level on comprehending, actingupon and sharing of agro advisories. Journal of Agriculture and Rural Development in the Tropics and Subtropics. 2:167-172.

Heckathorn DD. 2011. Snowball versus respondentdriven sampling. Journal of Sociological Methodology. 1:355-366.

Huyen LTT, P Herold, A Markemann and AV Zarate. 2011. Resource use, cattle performance and output patterns on different farm types in mountainous province of northern Vietnam. Journal of Animal Production Science. 7:650-661.

Huyen LTT, DTT Van, A Markemann, P Herold and AV Zarate. 2012. Beef cattle keeping by smallholders in a mountainous province of northern Vietnam in relation of poverty status, community remoteness and ethnicity. Journal of Animal Production Science. 2:163-172.

Kay RD, WM Edwards and PA Duffy. 2008. Farm Management. Sixth Edition. McGraw-Hill Companies Inc. 1221 Avenue, New York. Pp.6568.

Maart-Noelck SC and O Musshof. 2013. Investing today or tomorrow? An experimental approach to farmers' decision behaviour.Journal of Agricultural Economics. 2:295-318.

Ndoro JT, M Mudhara and M Chimonyo. 2014. Livestock extension programmes participation and impact on smallholder cattle productivity in KwaZulu-Natal: A propensity score matching 
approach. South African Journal of Agricultural. 2:62-80.

Paudel KP, NR Martin, G Wehtje and T Grey. 2013. Economic decision making using Enterprise Budgeting and Statistical Analysis: An Illustration in Wed Control Practices in Peanut Production. Journal of Production Agriculture. 1: 48-52.

Penson JB, O Capps and CP Rosson. 2002. Introduction to Agricultural Economics. Pearson education, Inc., Upper Saddle River, New Jersey. p. 270-277.

Salganik MJ and DD Heckathorn. 2004. Sampling and estimation in hidden populations using respondent-driven sampling. Journal of Sociological Methodology. 1:193-240.

Stür W, TT Khanh and A Duncan. 2013. Transformation of smallholder beef cattle production in Vietnam. Int. Journal of Agricultural Sustainability. 4: 363-381.

Syamsu JA, M Yusuf and A Abdullah. 2014. Characteristics of feed mills at farmers group scale in supporting the development of beef cattle. Journal of Advanced Agricultural Technologies. 1:24-27.

Verschelde $M, M D^{\prime}$ Haese, $G$ Rayp and $E$ Vandamme. 2013. Challenging small-scale farming: a non-parametric analysis of the (inverse) relationship between farm productivity and farm size in Burundi. Journal of Agricultural Economics 2:319-342.

Widiati R. 2006. The integration of beef cattle farming system on the farm household in Merapi Volcanic Slope, Sleman Yogyakarta (The application of linear programming analysis model toward sustainable livestock development). In: Proceeding 4th Int Semin Trop Anim Prod Fac Anim Sci Gadjah Mada Univ. Yogyakarta (Indonesia): Gadjah Mada University. p. 536-541.

Widiati R. 2012. Financial feasibility of beef cattle breeding with various capital aids in rural area of Gunungkidul District of Yogyakarta. Bulletin of Animal Science. 2: 1-7.

Widiati R. 2014. Developing beef cattle industry at smallholders to support beef selfsufficiency.Wartazoa24 (4):191-200.

Widi TSM. 2015. Mapping the impact of crossbreeding in smallholder cattle systems in Indonesia. Ph.D Thesis: Wageningen University, The Netherlands.

Widi TSM, HMJ Udo, K Oldenbroek, IGS Budisatria, EBaliarti, and AJ van der Zijpp. 2015. Is crossbreeding beneficial for mixed farming systems in Central Java?. Journal of Animal Genetic Resources. 56:127-144. Doi:10.1017/\$207863361500028. 